\title{
Human Insulinoma: Clinical, Cellular, and Molecular Aspects ${ }^{*}$
}

\author{
Paul Komminoth, MD, 1,2 Philipp U. Heitz, MD, \\ and Jürgen Roth, MD, PHD ${ }^{1}$
}

\begin{abstract}
Insulinoma is the most frequently encountered functioning endocrine pancreatic tumor in humans. In this overview we summarize morphological and clinical features of insulinomas, report about the proinsulin-insulin conversion in normal and neoplastic Bcells, discuss the new classification, the criteria of malignancy, and the clonal composition of endocrine pancreatic tumors, and outline recent findings on the molecular pathology of these tumors.
\end{abstract}

Key Words: Pancreas, insulin, molecular pathogenesis

\section{Introduction}

Endocrine pancreatic tumors (EPTs) have a prevalence of approx 1 in a population of 100,000 and an incidence of 1 per $10^{6}$ per year for insulinomas and gastrinomas, and one of 1 per $10^{7}$ per year for the other tumors.

EPTs giving rise to well-defined hormonal syndromes are designated "functioning" and are classified according to the hormone responsible for the clinical syndrome. "Nonfunctioning" (nonsecreting, inactive, hormonally silent) EPTs do not lead to endocrinological symptoms and may be named according to the major product detected by immunohistochemistry or radioimmunoassay, i.e., "EPT with production of insulin."

In surgical series, functioning EPTs account for $60-85 \%$ of all EPTs [1]. Clinically unrecognized and asymptomatic tumors, usually smaller than $1 \mathrm{~cm}$ in diameter, are found in $0.4-1.5 \%$ of unse- lected autopsies [2]. In surgical series, nonfunctioning tumors comprise $15-21 \%$ of all EPTs [1]; in our series of 501 tumors, it is the largest group representing $34 \%$ of all EPTs [3] Approximately 25\% of all EPTs are associated with multiple endocrine neoplasia type 1 (MEN1).

Although previously thought to arise from neural ectoderm, the neuroendocrine cells of the gastrointestinal system, including the pancreas, are derived from endoderm $[4,5]$. However, whether EPTs originate from the ductular epithelium or the islet cells of the pancreas is still a matter of debate [6].

Precise classification of EPTs requires analysis of the cell phenotype by immunohistochemistry (Tables 1 and 2). Because the tumors originate from cells that are "phenotypically" neuroendocrine, they share broad spectrum markers for neuroendocrine differentiation, such as neuron-specific-enolase (NSE), synaptophysin, and 
chromogranin A. In the majority of functioning tumors, the hormone causing the syndrome can be detected by immunohistochemistry at the light and electron microscopic level. Staining intensity or number of positive cells, however, are not related to the severity of symptoms. Using a panel of antibodies against pancreatic hormones, many tumors turn out to be multihormonal. Nonfunctioning tumors frequently exhibit positivity for a variety of hormones, without causing clinical symptoms.

\section{Clinical Features of Insulinomas}

Symptoms of hypoglycemia due to hypersecretion of insulin were first described by Harris in 1924 [7], and three years later the association between insulinsecreting EPTs and hypoglycemia was recognized by Wilder et al. [8].

Insulinomas are by far the most frequent of all funcrioning EPTs (prevalence: 1-1.25 per $10^{6}$ of people; incidence: four patients per $10^{6}$ person years) $[9,10]$. Insulinomas have been diagnosed in all age groups, but rarely occur in adolescence. The highest incidence is found between 40 and $60 \mathrm{yr}$, with an average age of $44-46 \mathrm{yr}$. Approximately $10 \%$ of the patients are younger than age 20 and $10 \%$ older than 60 . There is $60: 40$ ratio of females to males in most reported series [1].

It is generally accepted that the vast majority of insulinomas are benign. The percentages of malignant tumors range from 2.4 to $17.9 \%$, with an average of $8.4 \%$ [10 14]. Malignant insulinomas occur in an older age group and have not been reported in children [15]. It appears that males are more frequently affected than females [16].

Virtually all functioning insulinomas manifest with symptoms of hypoglycemia, which include adrenergic and hypo-gly- copenic signs [17]. A gradual onset of sweating and palpitations (warning symptoms) in hypoglycemia is typical. More than $80 \%$ of patients have transient symptoms of CNS dysfunction, ranging from drowsiness to coma and epilepsia, and there are several reports of insulinoma patients with erroneous psychiatric or neurologic diagnoses [13].

The diagnosis of an insulinoma is mainly based on laboratory examinations and provocative tests. Inappropriate insulin values in relationship to the plasma glucose level are key characteristics of hyperinsulinemic hypoglycemia due to an insulinoma. In healthy individuals the plasma insulin is suppressed to less than $6 \mu \mathrm{U} / \mathrm{mL}$ during hypoglycemia $(\leq 40 \mathrm{mg} / \mathrm{dL} ; 2.2 \mathrm{mM})$ and the ratio of glucose to insulin is greater than 2.5. The measurement of plasma proinsulin can also be helpful in the diagnosis of insulinoma. The majority of patients present proinsulin levels of more than $22 \%$ of the total plasma insulin, and it has been shown that especially malignant tumors present high plasma proinsulin levels $[18,19]$.

Provocative tests include monitored fasting and secretagogue stimulation of insulin by tolbutamide, glucagon, or calcium. The demonstration of low plasma glucose, and elevated or normal insulin in the absence of ketonuria suggests an insulinoma. Insulinoma patients typically demonstrate unchanged C-peptide levels, owing to continuous insulin secretion by the tumor [20].

Methods of localizing insulinomas include noninvasive techniques such as ultrasonography, bolus-enhanced computed tomography (CT), magnetic resonance imaging, and octreotide scan, as well as invasive techniques such as arteriography with or without substraction and transhepatic portal venous sampling. 
Table 1. Classification of EPT

1. Well-differentiated endocrine tumor

1.1. Functioning

Insulin-producing (insulinoma)

Glucagon-producing (glucagonoma)

Somatostatin-producing (somatostatinoma)

Gastrin-producing (gastrinoma)

VIP-producing (vipoma)

Serotonin producing tumor with carcinoid syndrome

Others

1.2. Nonfunctioning

Microadenoma $(<0,5 \mathrm{~cm})$

Others

2. Well-differentiated endocrine carcinoma

2.1. Functioning (see 1.1. for types)

2.2. Nonfunctioning

3. Poorly differentiated endocrine carcinoma

4. Mixed exocrine-endocrine tumor

5. Tumor-like lesions

Islet hyperplasia

Nesidioblastosis

Endocrine dysplasia

Table 2. Clinicopathologic Correlations

1. Well-differentiated endocrine tumor

benign behavior: confined to the pancreas,

nonangioinvasive, $<2 \mathrm{~cm}$ in size

Functioning

Insulinoma

Nonfunctioning

uncertain behavior, confined to the pancreas; $\geq 2 \mathrm{~cm}$ in size or angioinvasive

Functioning

Gastrinoma, insulinoma, vipoma, glucagonoma,

somatostatinoma or inappropriate syndrome* tumor

Nonfunctioning

2. Well-differentiated endocrine carcinoma

low grade malignant with gross local invasion and/or metastases

Functioning

Gastrinoma, insulinoma, glucagonoma, vipoma,

somatostatinoma or inappropriate syndrome" tumor

Nonfunctioning

3. Poorly differentiated endocrine carcinoma

high grade malignant (small to intermediate cell) carcinoma

$<2 \mathrm{~cm}$ in size implies near $100 \%$ probability of benign behavior; $<3 \mathrm{~cm}$ corresponds to $90 \%$ probability.

" Inappropriate hormone syndromes: Cushing (ACTH), acromegaly or gigantism (GRH), hypercalcemia, and so on.

Strategies for insulinoma treatment include surgical removal or debulking of tumor tissue, including liver transplantation in case of metastases [21], drug therapy aimed at palliation of symptoms referable to hypoglycemia [22], and chemotherapy in patients with metastatic disease [23]. About two-thirds of the patients can be cured by resection of the tumor. Blind distal pancreas resection is indicated in 
patients where the tumor cannot be located during operation and measurement of changes in plasma glucose during surgery is a helpful means in predicting a cure for the patient [24].

\section{(Histo)pathological Features of Insulinomas}

The majority of insulinomas occur in the pancreas or are attached to it. Extrapancreatic tumors are extremely rare $(1.8 \%)$ and are most commonly found in the duodenal wall [25,26]. Macroscopically insulinomas are usually red-brown in color and are softer than the surrounding pancreatic tissue, with the exception of tumors with a large amount of fibrous stroma and/or amyloid. Collective data indicate that tumors are equally distributed between the head, body, and tail of the pancreas with a slight predominance of the head and tail region [25-28]; $83 \%$ of insulinomas occur single, $11-13 \%$ multiple, and $4 \%$ are associated with MEN1 [29]. Functioning insulinomas are frequently discovered while still small and the reported mean size of the tumors has varied from microscopic up to $11 \mathrm{~cm}: 75 \%$ of the tumors are between $0.5-$ $2 \mathrm{~cm}$ and weigh less than $2 \mathrm{~g}$. Symptoms of hypoglycemia are unrelated to the size of tumor [18]. Only $8 \%$ of tumors are larger than $5 \mathrm{~cm}$ [25]. These tumors are more likely to be malignant than smaller ones.

The insulinomas producing a hypoglycemic syndrome in MEN1 patients are usually larger than $1 \mathrm{~cm}$, and microadenomas with insulin expression, no matter how numerous they are, seem to remain functionally silent. This implies that the insulinomas in MEN1 patients are among the grossly apparent and palpable pancreatic tumors. If there are several large tumors, usually only one of them is an insulinoma. Multiple large insulinomas are rare.
Several histological classifications have been proposed for sporadic insulinomas [30-32]. However, the clinical relevance of such classifications is not proven. Most insulinomas store insulin and proinsulin in a sufficient amount to be easily visualized by immunohistochemistry. Typically insulin-rich cells account for $60-80 \%$ of all tumor cells. However, the amount of immunohistochemical presence of insulin does not correlate with hormone levels in the serum. About half of the insulinomas are multihormonal. In such tumors insulin-rich cells are admixed with cells producing glucagon, somatostatin, or pancreatic polypeptide. Amyloid deposition is a common finding in insulinomas and immunohistochemical detection of islet amyloid polypeptide (IAPP) or amylin, a possible causative factor for amyloid deposition, has recently been described in 16 out of 19 tumors [33].

\section{Proinsulin-Insulin Conversion in Insulinomas}

The biosynthesis of insulin commences in the endoplasmic reticulum (ER), and the preproinsulin becomes converted to proinsulin in the ER by the action of a signal peptidase. This is followed by various posttranslational processing steps involving the action of two prohormone-converting endoproteases and of carboxypeptidase $\mathrm{H}$. Each of the two endoproteases preferentially cleaves one of the two dibasic cleavage sites in proinsulin, followed by the removal of the $\mathrm{C}$-terminal basic residue by carboxypeptidase $\mathrm{H}$. Thus, two cycles of combined endoprotease-carboxypeptidase action are required to generate mature insulin and C-peptide from proinsulin. These processing steps are accompanied by the sorting and packing of insulin into secretory granules. The combination of 
biochemical and immunohistochemical approaches has permitted the fine analysis of the proinsulin-insulin conversion in normal pancreatic beta cells [3]. In light microscopic studies, the proinsulin-specific monoclonal antibody GS-9 A 8, recognizing an epitope around the dibasic processing site $\operatorname{Arg} 31-\operatorname{Arg} 32$, resulted in a Golgi-like staining pattern (Fig. 1). By immunoelectron microscopy, this antibody provided in situ evidence that the proinsulin-insulin conversion takes place in partially clathrin-coated, acidic immature secretory granules. Subsequent immunoelectron microscopic studies provided evidence that the endoproteolytic cleavage at the dibasic pair Lys64-Arg65 in the A chain/C-peptide junction also occurred in the clathrin-coated immature secretory granules. These data were complemented by microscopic studies, applying a monoclonal antibody specific for insulin. By light microscopy, a diffuse cytoplasmic labeling for insulin was evident (Fig. 1). By immunoelectron microscopy, insulin immunolabeling first became detectable in clathrin-coated immature secretory granules, which upon acidification transformed in mature secretory granules and exhibited highest labeling for insulin. Thus, in normal pancreatic beta cells, proinsulin-insulin conversion occurs in acidic immature secretory granules of the trans Golgi apparatus (Fig. 2).

Insulinomas can exhibit many structural and immunohistochemical features, in common with normal beta cells. However, even within a given insulinoma, insulin immunostaining and ultrastructural details of secretory granule morphology may vary greatly. Variability is also observed in their clinical manifestations. We have investigated the distribution pattern of proinsulin and insulin by light and electron microscopic immunolabeling, applying the proinsulin and insulin-specific monoclonal antibodies [34,35]. By light microscopy, 76 human insulinomas were studied. One trabecular and two solid insulinomas showed the staining patterns of normal beta cells. A "near normal" staining pattern, perinuclear proinsulin and diffuse or polarized insulin staining (Fig. 1), existed in 10/27 trabecular and 11/44 solid insulinomas. An "intermediate" staining pattern, intense perinuclear as well as weaker diffuse proinsulin staining with diffuse or polarized insulin staining (Fig. 1) was observed in 10/27 trabecular and 20/44 solid insulinomas. Of the five glandular insulinomas, four exhibited a "near normal" and one an "abnormal" staining pattern. Similar results were obtained by others in a recent immunohistochemical study [36], which also addressed the immunohistochemistry of the prohormone processing enzymes. In our studies, no correlation was found among any particular staining pattern, histological type, the multihormonality, or the malignancy of the insulinomas [35]. The abnormal labeling pattern for proinsulin in about $60 \%$ of the insulinomas was suggestive of topographical abnormalities of hormone conversion and an immunoelectron microscopic study was carried out in seven such insulinomas [34]. We found that, in contrast to normal beta cells, the proinsulin-insulin conversion in insulinomas occurred already in the Golgi apparatus (Fig. 3), but remained incomplete, resulting in the formation of secretory granules containing both proinsulin and insulin (Figs. 2 and 3). This indicates that in insulinoma sorting into secretory granules may not be a prerequisite for hormone conversion. It also indicates that proinsulin and insulin storage and secretion occur through secretory granules via the regulated secretory pathway. A substantial variability for both proinsulin and insulin immunolabeling in secretory granules was observed not only in individual tumor cells, but also 

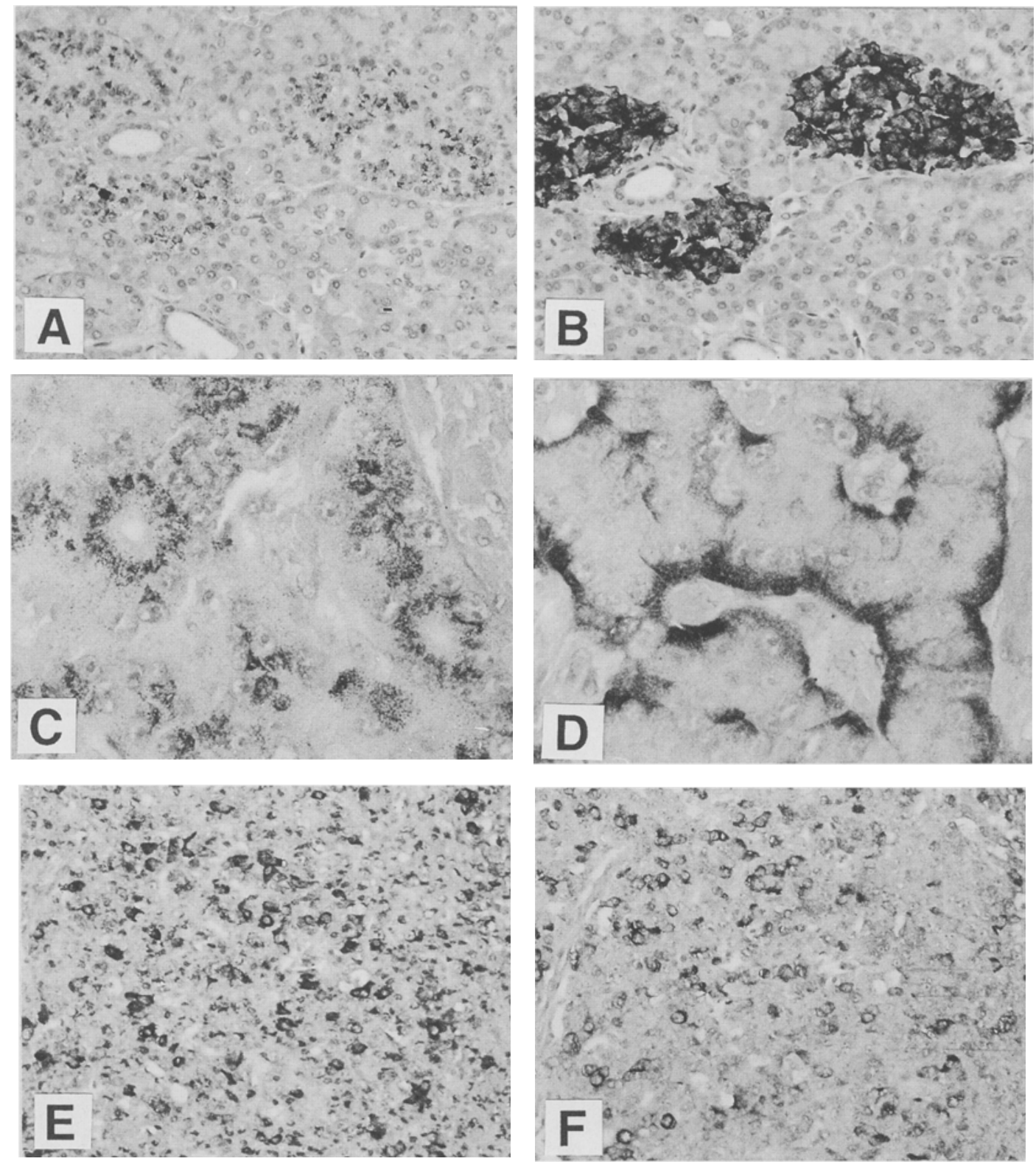

Fig. 1. Immunohistochemical detection of proinsulin $(A, C, E)$ and insulin $(\mathbf{B}, \mathbf{D}, \mathbf{F})$ in human pancreas and insulinomas, paraffin sections, silver-intensified immunogold staining using monoclonal antibodies specific for proinsulin and insulin. In islets of Langerhans of normal human pancreas, proinsulin immunohistochemistry results in a perinuclear crescent-shaped, Golgi staining pattern (A). Insulin immunostaining in a serial section consecutive to the one shown in (A) results in a diffuse cytoplasmic labeling (B). Insulinomas may exhibit a near normal perinuclear proinsulin staining $(C)$ and a polarized cytoplasmic insulin staining (D). However, insulinomas may show an abnormal diffuse proinsulin staining pattern (E). Insulin immunostaining in a consecutive serial section from the insulinoma shown in (E) is presened in (F).

among the insulinomas studied. This variability may account for the lack of correlation between pathohistological, immunohistochemical, and clinical parameters in functioning insulinomas [34-36].

\section{Criteria of Malignancy in EPTs}

Based on the work of Capella et al. [37], the World Health Organization (WHO) has elaborated a new classification of neuroendocrine tumors including EPTs, 


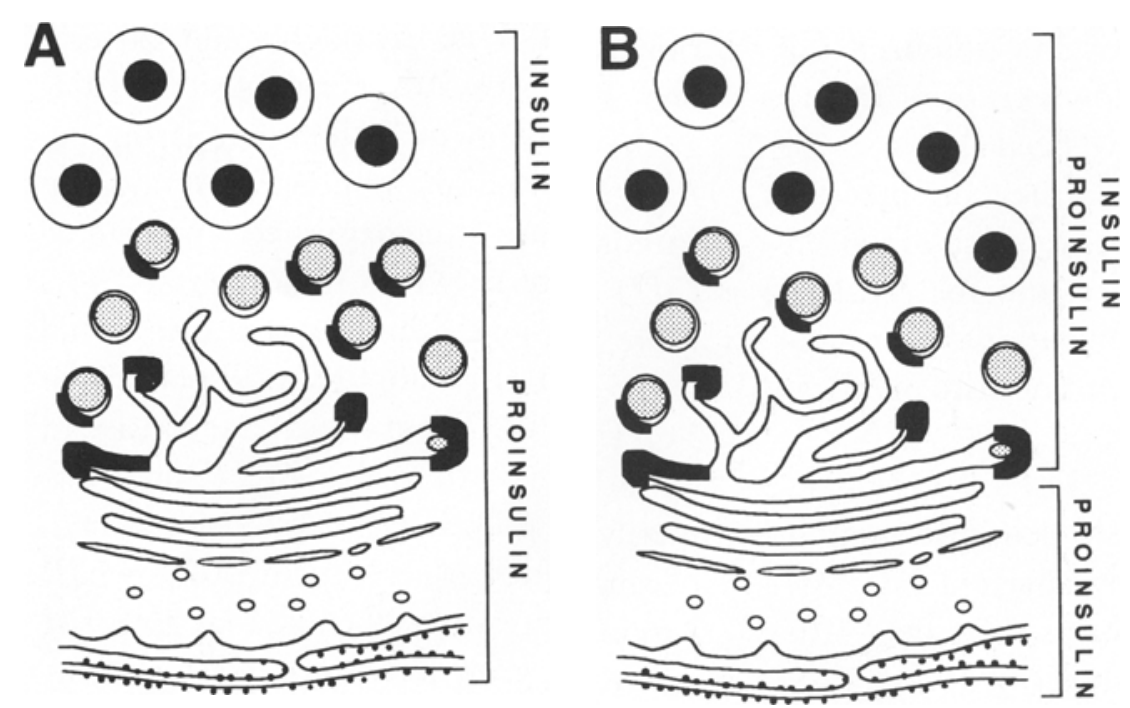

Fig. 2. Schematic presentation of proinsulin-insulin conversion in normal pancreatic beta cells (A) and human insulinoma (B). For details, see text. which is currently in press and has been presented in review articles [38,39]. In the new classification (Table 1), tumors smaller than $2 \mathrm{~cm}$ in size, confined to the pancreas, without angio-invasion or metastases and with a mitotic rate of less than 2 mitoses per 10 high power fields or less than $2 \% \mathrm{Ki}$ 67 (or MiB-1) staining index are considered benign. However, the only reliable criteria for malignancy are the infiltration of the tumor into adjacent organs (e.g., the spleen), the presence of angioinvasion of lymph node, and/or distant metastases [40].

It has been hypothesized that immunohistochemical markers might be helpful in identifying tumors with a more aggressive
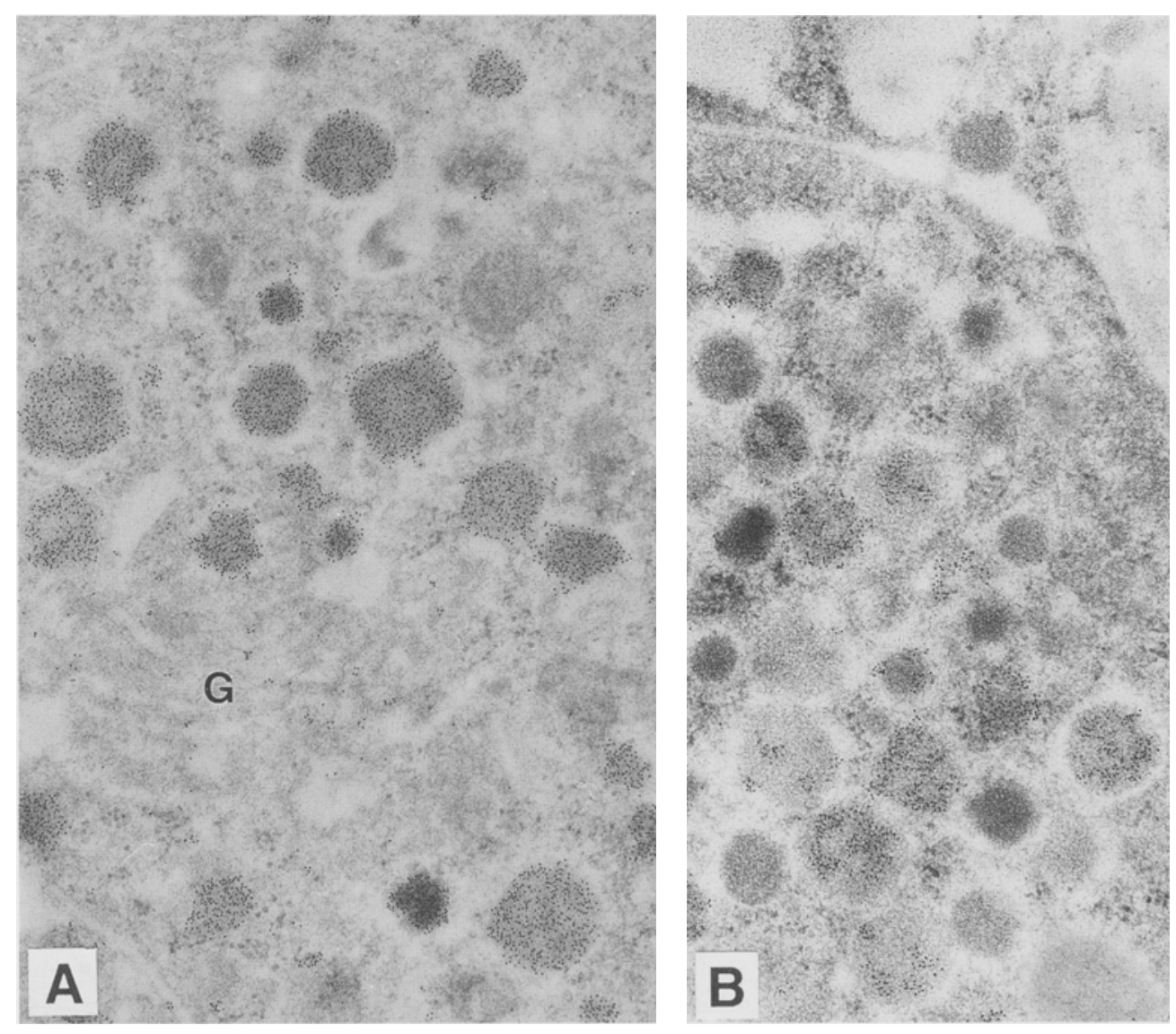

Fig. 3. Immunoelectron microscopic demonstration of proinsulin and insulin in a human insulinoma, immunogold labeling, Lowicryl K4M thin sections. Insulin immunoreactivity as indicated by the electron dense gold particles is present over the Golgi apparatus (G)and electron dense core secretory granules (A). Immunogold labeling for proinsulin can be found also in secretory granules in the periphery of the insulinoma cells (B). 
biological behavior or the potential for metastatic disease. However, most of the proposed markers have been shown to be only of limited value in the daily practice [41] and the individual prognosis of a given patient with an EPT cannot be satisfactorily predicted by conventional histological parameters or immunohistochemical expression patterns.

Thus, in a study on $53 \mathrm{EPTs}$ ( 38 benign, 15 malignant) we could demonstrate that the expression of polysialylated NCAM, NCAM protein isoforms, and beta-1,6branched, asparagine-linked oligosaccharides, which have been associated with increased aggressiveness, metastatic potential, and survival in other tumor types [42], are not suitable to distinguish between malignant and benign EPTs. Polysialylated NCAM was not detectable in benign and malignant insulinomas, and the NCAM protein isoform pattern was similar as well. Furthermore, 11/15 (74\%) of the malignant and 23/38 (63\%) of the benign tumors exhibited staining for beta-1,6branches [43]. In another study on 134 neuroendocrine tumors of different locations, including 27 EPTs (6 insulinomas, 10 gastrinomas, 1 glucagonoma, 3 somatostatinomas, 7 VIPomas), we could demonstrate that not only gastrinomas and nonfunctioning EPTs (as reported by other groups) but also other types of EPTs may express the glycoprotein CD44 and its isoforms and that the expression of CD44 is not associated with a malignant phenotype or tumor progression as reported for other types of human tumors [44].

\section{Clonal Composition of EPTs}

In a study on the clonality of 34 malignant and benign EPTs of different types from female patients [44], we have shown that $7 / 20$ of the informative tumors exhibited a monoclonal (35\%), 10/20 a polyclonal, 1/20 an oligoclonal pattern, and 2/20 a loss of heterozygosity ( $\mathrm{LOH}$ ) at the Xq12-locus. When comparing benign and malignant neoplasms, benign tumors more often exhibited a polyclonal (5/7) pattern, while malignant tumors more frequently showed a monoclonal $(8 / 13)$, an oligoclonal $(1 / 20)$ pattern, or LOH $(2 / 20)$. These results are consistent with the hypothesis that EPTs might primarily be polyclonal or oligoclonal neoplasms, which are eventually outgrown by a more aggressive cell clone that gives rise to invasive growth and/or metastasis. Furthermore, we postulated that the X-chromosome, which was lost in two of the examined highly malignant EPTs, might play a role in the progression of EPTs by inactivation of a not yet identified tumor suppressor gene [45].

\section{Molecular Pathogenesis of EPTs}

Although the molecular basis of the familial EPTs (which are associated with MEN1 and VHL) has recently been established [46,47], only little is known about the oncogenesis and the molecular basis of progression of sporadically occurring EPTs. A small number of published studies indicate that in contrast to other human tumors, the activation of oncogenes is not an early event in EP'Ts. It was shown that, for example, the protein- and RNAexpression (but not mutations) of $\mathrm{H}$-ras and $K$-ras is associated with the progression of sporadic EPTs and oncogenes (such as fos, $c-m y c, M-m y c$, and sis) or tumor suppressor genes (such as $p 53$ and $R b$ ), which are frequently mutated or activated in other human tumors, appear not to be involved in the neoplastic transformation of EPTs, or merely involved as a late event [48-51]. Furthermore, in an analysis of 112 sporadic neuroendocrine tumors for $R E T$ - 
protooncogene mutations, we found that the 17 examined EPTs lacked mutations in all five examined $R E T$-protooncogene exons, which indicates that this gene is not generally important in the tumorigenesis of EPTs [52].

Molecular and cytogenetic analysis have led to the identification of a number of chromosomal alterations in EPTs. However, no consistent pattern has been noted so far. There are indications that certain chromosomal abnormalities are more frequently encountered in EPTs.

Several LOH studies have shown that the chromosome $11 \mathrm{q} 13$ region is deleted in a subset of EPTs $[51,53]$. The chromosomal region $11 \mathrm{q} 13$ is the locus of the recently identified $M E N 1$ gene. Thus, it is tempting to assume that $M E N 1$ mutations are also involved in the formation of sporadic EPTs. However, we and others [53-55] could only identify a small percentage of sporadic EPTs harboring somatic mutations in the $M E N 1$ gene, indicating that this gene is only involved in a subset of EPTs and that the majority of EPTs are probably caused by other genetic lesions. In the study of Zhuang et al. on 12 sporadic insulinomas, only two tumors exhibited an inactivating $M E N 1$ gene mutation [53] and in our own series of $30 \mathrm{EPTs}$ we have observed a mutation rate of only $4 / 30(13.3 \%)$. The series also included nine insulinomas, which exhibited frequencies of $44.4 \%$ for $\mathrm{LOH}(4 / 9)$ and $11.1 \%$ for mutations (1/9) [54-56].

$\mathrm{LOH}$ studies on other loci did not reveal any other concise candidate gene for the initiation or progression of sporadic EPTs $[50,51,57]$. For example, it recently has been demonstrated that loss of chromosome 3 p25 in sporadic EPTs is associated with a more aggressive phenotype [58] and that no mutations of the VHL gene (which is located in this particular region of the chromosome) is present in these tumors [58]. Further chromosomal loci that have been occasionally found deleted in sporadic EPTs include chromosome $1 \mathrm{p}, 5 \mathrm{q}, 9 \mathrm{q}, 7 \mathrm{q}$, and $16 q[60,61]$.

Only a few publications exist on cytogenetic aberrations in EPTs $[62,63]$. They were mainly observed in cultured tumor cells and the identified changes were not confirmed by LOH or FISH methods. One study on cultured EPTs of nine patients showed a multitude of chromosomal aberrations in half of the investigated tumors. However, no consistent aberration has been noted and cytogenetical findings were not correlated with clinical data [63]. Another recently published study on 16 insulinomas from transgenic mice (with a SV40-large-T-antigen transgene under the control of the rat insulin promoter) reported $\mathrm{LOH}$ on the mouse chromosomes 9 and 16, which are homologous to the human chromosome regions $6 \mathrm{p}, 3 \mathrm{p}, 3 \mathrm{q}$ and $22 q, 21 q, 3 q$, respectively, in a majority of examined tumors [61]. In the same study, additional losses on chromosomes $2,6,7,11,13$, and 14 could be identified using comparative genomic hybridization (CGH). In our own CGH study, we have analyzed 44 benign and malignant EPTs, in order to correlate the overall number of genetic alterations with clinical and histopathological parameters and to identify chromosomal regions that might harbor genes involved in EPT initiation and progression. Aberrations were found in 36 EPTs and chromosomal losses were slightly more frequent than gains. The most frequent losses involved $Y, 6 q, 11 q, 3 p, 3 q$, $11 \mathrm{p}, 6 \mathrm{p}, 10 \mathrm{q}$, and $\mathrm{Xq}$, and most common gains included $7 q, 17 q, 5 q, 14 q, 7 p, 9 q$, $17 p, 20 q, 12 q$, and Xp. A correlation was found between the total number of genetic changes per tumor and both tumor size and disease stage. In particular, losses of $3 p$ and 
$6 \mathrm{q}$ and gains of $14 \mathrm{q}$ and $\mathrm{Xq}$ were found to be associated with metastatic disease. Furthermore, characteristic patterns of genetic changes were found in the various EPT subtypes, e.g., 6q loss in malignant insulinomas, indicating that these groups might evolve along genetically different pathways. The highlighted genetic aberrations, including the newly found involvement of $6 \mathrm{q}$ losses and sex chromosome alterations, should stimulate the further analysis of these chromosomal regions, which may lead to the discovery of novel genes important in the tumorigenesis and evolution of EPTs $[64,65]$.

\section{Acknowledgments}

The authors thank Parvin Saremaslani, Seraina Muletta-Feurer, and Kathrin Rütimann for their excellent technical assistance.

\section{References}

1. Klöppel G, In't Veld P, Komminoth P, Heitz PU. The endocrine pancreas. In: Kovacs K, SL Asa, eds. Functional endocrine neoplasia. Oxford: Blackwell Scientific Publications 415-487, 1998.

2. Grimelius L, Hultquist G, Stenquist B. Cytological differentiation of asymptomatic pancreatic islet cell tumors in autopsy material. Virchows Arch [a] Pathol Anat 365:275-288, 1975.

3. Roth J, Komminoth P, Klöppel G, Heitz PU. Diabetes and the endocrine pancreas. In: Damjanov I, DT Purtilo, eds. Anderson's Pathology, 10th Edition. St. Louis, Chicago: Mosby Year Book 2042-2070, 1996.

4. Le Douarin NM. On the origin of pancreatic endocrine cells. Cell 53:169-171, 1988.

5. Andrew A, Kramer B, Rawdon BB. The origin of gut and pancreatic neuroendocrine (APUD) cells-the last word? [editorial] [In Process Citation]. J Pathol 186:117-118, 1998.

6. Rindi G, Bishop AE, Murphy D, Solcia E, Hogan B, Polak JM. A morphological analy- sis of endocrine tumour genesis in pancreas and anterior pituitary of AVP/SV 40 transgenic mice. Virchow Arch 412:255-266, 1988.

7. Harris S. Hyperinsulinism and dysinsulinism. JAMA 83:729-733, 1924.

8. Wilder RM, Allan FN, Power MH, Robertson HE. Carcinoma of the islands of the pancreas; hyperinsulinism and hypoglycemia. JAMA 89:348-355, 1927.

9. Boden G. Glucagonomas and insulinomas. Gastroenterol Clin North Am 18:831-845, 1989.

10. Service FJ, McMahon MM, O'Brien PC, Ballard DJ. Functioning insulinoma - incidence, recurrence, and lingterm survival of patients: a 60-year study. Mayo Clin Proc 66:711-719, 1991.

11. Galbut DL, Markowitz AM. Insulinoma: Diagnosis, surgical management and long-term follow-up. Am J Surg 139:682-690, 1980.

12. Giercksky KE, Halse J, Mathisen W, Gjone E, Flatmark A. Endocrine tumors of the pancreas. Scand J Gastroenterol 15:129-135, 1980.

13. Glickman MH, Hart MJ, White TT. Insulinoma in Seattle: 39 cases in 30 years. Am J Surg 140:119-123, 1980.

14. Le Quesne P, Nabarro JDN, Kurtz A, Zweig S. The management of insulin tumors of the pancreas. Br J Surg 66:373-378, 1979.

15. Stringel G, Dolpe-Scott M, Perelman AH. The occult insulinoma operative localization by quick insulin radioimmunoassay. J Pediatr Surg 20:734-736, 1985.

16. Danforth DH, Gorden P, Brennan MF. Metastatic insulin secreting carcinoma of the pancreas. Clinical course and the role of surgery. Surgery 96:1027-1037, 1984.

17. Crain EL, Thorn GW. Functioning pancreatic islet cell adenomas: a review of the literature and presentation of two new differential tests. Medicine 28:427-447, 1949.

18. Fajans SS, Vinick AI. Insulin-producing islet cell tumors. Endocrinol Metab Clin North Am 18:45-74, 1989.

19. Turner RC, Heding LG. Plasma proinsulin, $\mathrm{C}$-peptide and insulin in diagnostic suppression tests for insulinoma. Diabetologica 13:571-577, 1977.

20. Comi RJ, Gorden P, Doppman JL. Insulinoma. In: Go VLW, EP Di Magno, JD Gardner, E Lebenthal, HA Reber, GA Scheele, 
eds. The pancreas: biology, pathobiology and disease. New York: Raven Press 979-996, 1993.

21. Lehnert T. Liver transplantation for metastatic neuroendocrine carcinoma: an analysis of 103 patients. Transplantation 66:1307-1312, 1998.

22. Oberg K, Eriksson B. The role of interferons in the management of carcinoid tumors. Acta Oncol 30:519-522, 1991.

23. Perry RR, Vinik AI. Diagnosis and management of functioning islet cell tumors. J Clin Endocr Metabol 80:2237-2278, 1995.

24. Krentz AJ, Hale PJ, Baddeley RM. Intraoperative blood glucose and serum insulin concentrations in the surgical management of insulinoma. Postgrad Med J 66:24-27, 1990.

25. Stefanini P, Carboni M, Patrassi N, Basoli A. Beta-islet cell tumors of the pancreas: results of a study on 1'067 cases. Surgery 75:597$609,1974$.

26. Filipi CJ, Higgins GA. Diagnosis and management of insulinoma. Am J Surg 125:231239, 1975.

27. Howard TJ, Stabile BE, Zinner MJ, Chang S, Bhagavan BS, Passaro EJ. Anatomic distribution of pancreatic endocrine tumors. Am J Surg 159:258-264, 1990.

28. Moss NH, Rhoades JE. Hyperinsulinism and islet cell tumors of the pancreas. In: Howard JM, GL Jordan, eds. Surgical diseases of the pancreas. Philadelphia: Lippincott, 1960; $321-441$.

29. Komminoth P, Heitz PU, Klöppel G. Pathology of MEN-1: Morphology, clinicopathologic correlations and tumor development. Int J Med 243:455-464, 1997.

30. Berger M, Bordi C, Cuppers HJ, Berchtold P, Gries FA, Munterfering H, Sailer R, Zimmermann H, Orci L. Functional and morphologic characterization of human insulinomas. Diabetes 32:921-931, 1983.

31. Creutzfeldt C, Track NS, Creutzfeldt W. In vitro studies of the rate of proinsulin and insulin turnover in seven human insulinomas. Eur J Clin Invest 3:371-384, 1973.

32. Heitz PU. Pancreatic endocrine tumours. In: Klöppel G, PU Heitz, eds. Pancreatic pathology. Edinburgh, London, Melbourne, New York: Churchill Livingstone, 1984; 206-239.

33. Williams AJ, Coates PJ, Lowe DG, McLean $\mathrm{C}$, Gale EA. Immunochemical investigation of insulinomas for islet amyloid polypeptide and insulin: evidence for differential synthesis and storage. Histopathology 21:215-223, 1992.

34. Roth J, Komminoth P, Heitz PU. Topographic abnormalities of proinsulin to insulin conversion in functioning human insulinomas. Comparison of immunoelectron microscopic and clinical data. Am J Pathol 147:489-502, 1995.

35. Roth J, Klöppel G, Madsen OD, Storch MJ, Heitz PU. Distribution patterns of proinsulin and insulin in human insulinomas: an immunohistochemical analysis in 76 tumors. Virchows Arch B 63:51-61, 1992.

36. Azzoni C, D'Adda, T, Tamburrano G, Coscelli C, Madsen OD, Scopsi L, Bordi C. Functioning human insulinomas. An immunohistochemical analysis of intracellular insulin processing. Virchows Arch 433:495-504, 1998.

37. Capella C, Heitz PU, Hofler H, Solcia E, Kloppel G. Revised classification of neuroendocrine tumors of the lung, pancreas and gut. Digestion 55(suppl 3):11-23, 1994.

38. Klöppel $\mathrm{G}$. Classification of neuroendocrine tumors. Verh Dtsch Ges Path 81:111-117, 1997.

39. Rindi G, Capella C, Solcia E. Cell biology, clinicopathological profile, and classification of gastro- enteropancreatic endocrine tumors. J Mol Med 76:413-420, 1998.

40. Klöppel G, Höfler H, Heitz PU. Pancreatic endocrine tumours in man. In: Polak JM, eds. Diagnostic histopathology of neuroendocrine tumours. Edinburgh: Churchill Livingstone 91-121, 1993.

41. La Rosa S, Sessa F, Capella C, Riva C, Leone BE, Klersy C, Rindi G, Solcia E. Prognostic criteria in nonfunctioning pancreatic endocrine tumours. Virchows Arch 429:323-333, 1996.

42. Seelentag WKF, Li WP, Hsu-Schmitz SF, Heitz PU, Roth J. The prognostic value of 11,6-branched oligosaccharides in human colorectal carcinoma. Cancer Res. 58:5559_ 5564, 1998.

43. Li WP, Komminoth P, Zuber C, Klöppel G, Heitz PU, Roth J. Can malignancy in insulinoma be predicted by the expression patterns of beta 1,6 branching of asparaginelinked oligosaccharides and polysialic acid of the neural cell adhesion molecule? Virchows Arch 429:197-204, 1996. 
44. Komminoth P, Seelentag WK, Saremaslani P, Heitz PU, Roth J. CD44 isoform expression in the diffuse neuroendocrine system. II. Benign and malignant tumors. Histochem Cell Biol 106:551-62, 1996.

45. Perren A, Roth J, Muletta-Feurer S, Saremaslani P, Speel EJM, Heitz PU, Komminoth P. Clonal analysis of sporadic pancreatic endocrine tumours. J Pathol 186:363-371, 1998.

46. Chandrasekharappa SC, Guru SC, Manickam P, Olufemi S, Collins FS, Emmert-Buck MR, Debelenko LV, Zhuang Z, Lubensky IA, Liotta LA, Crabtree JS, Wang Y, Roe BA, Weisemann J, Boguski MS, Agarwal SK, Kester MB, Kim YS, Heppner C, Dong Q, Spiegel AM, Burns AL, Marx SJ. Positional cloning of the gene for multiple endocrine neoplasia-type 1. Science 276:404-406, 1997.

47. Latif F, Tory K, Gnarra J, Yao M, Duh FM, Orcutt ML, Stackhouse T, Kuzmin I, Modi W, Geil L, et al. Identification of the von Hippel-Lindau disease tumor suppressor gene (see comments). Science 260:1317-20, 1993.

48. Lohmann DR, Funk A, Niedermeyer HP, Haupel S, Hofler H. Identification of p53 gene mutations in gastrointestinal and pancreatic carcinoids by nonradioisotopic SSCA. Virchows Arch B Cell Pathol Incl Mol Pathol 64:293-6, 1993.

49. Höfler H, Ruhri C, Pütz B, Winsberger G, Hauser $\mathrm{H}$. Oncogene expression in endocrine pancreatic tumors. Virchows Arch B 55:355$361,1988$.

50. Iwamura Y, Futagawa T, Kaneko M, Nakagawa K, Kawai K, Yamashita K, Nakamura T, Hayashi $H$. Co-deletions of the retinoblastoma gene and Wilms' tumor gene and rearrangement of the Krev-1 gene in a human insulinoma. Jpn J Clin Oncol 22:6-9, 1992.

51. Sawicki MP, Wan YJ, Johnson CL, Berenson J, Gatti R, Passaro EJ. Loss of heterozygosity on chromosome 11 in sporadic gastrinomas. Hum Genet 89:445-449, 1992.

52. Komminoth P, Roth J, Muletta FS, Saremaslani P, Seelentag WK, Heitz PU. RET protooncogene point mutations in sporadic neuroendocrine tumors. J Clin Endocrinol Metab 81:2041-2046, 1996.

53. Zhuang $Z$, Vortmeyer $\mathrm{AO}$, Pack $S$, Huang $S$, Pham TA, Wang C, Park WS, Agarwal SK, Debelenko LV, Kester M, Guru SC, Manickam P, Olufemi SE, Yu F, Heppner C, Crabtree JS, Skarulis MC, Venzon DJ, Emmert BM,
Spiegel AM, Chandrasekharappa SC, Collins FS, Burns AL, Marx SJ, Lubensky IA, et al. Somatic mutations of the MEN1 tumor suppressor gene in sporadic gastrinomas and insulinomas. Cancer Res 57:4682-4686, 1997.

54. Görtz B, Roth J, Krähenmann A, de Krijger RR, Muletta-Feurer S, Rütimann K, Saremaslani P, Speel EJM, Heitz PU, Komminorh P. Mutations and allelic deletions of the MEN1 gene are associated with a subset of sporadic endocrine pancreatic and neuroendocrine tumors and not restricted to foregut neoplasms. Am J Pathol 154:429-436, 1999.

55. Görtz B, Roth J, Speel EJM, Krähenmann A, De Krijger RR, Matias-Guiu X, MulettaFeurer S, Rütimann K, Saremaslani P, Heitz PU, Komminoth P. MEN1 gene mutation analysis of sporadic adrenocortical lesions. Int J Cancer 80:373-379, 1999.

56. Görtz B, Muletta-Feurer S, De Krijger RR, Rütimann K, Speel EJM, Saremaslani P, Roth J, Heitz PU, Komminoth P. MEN-1 gene mutations in sporadic neuroendocrine and adrenocortical tumors. Path Res Pract 194:277 (Abstract), 1998.

57. Dietrich WF, Radany EH, Smith IS, Bishop JM, Hanahan D, Lander ES. Genome-wide search for loss of heterozygosity in transgenic mouse tumors reveals candidate tumor suppressor genes on chromosomes 9 and 16. Proc Nat Acad Sci U S A 91:9451-5, 1994.

58. Barghorn A, Rütimann K, Saremaslani P, Muletta S, Speel EJM, Roth J, Heitz PU, Komminoth P. Loss of heterozygosity von 3 p25 in sporadischen neuroendokrinen Pankreastumoren: ein Malignitätsmarker? Schweiz Med Wochenschr 128:1870 (Abstract 13), 1998.

59. Chung DC, Smith AP, Louis DN, GraemeCook F, Warshaw AL, Arnold A. A novel pancreatic endocrine tumor suppressor gene locus on chromosome $3 \mathrm{p}$ with clinical prognostic implications. J Clin Invest 100:404-410, 1997.

60. Radford DM, Ashley SW, Wells SJ, Gerhard DS. Loss of heterozygosity of markers on chromosome 11 in tumors from patients with multiple endocrine neoplasia syndrome type 1. Cancer Res 50:6529-6533, 1990.

61. Ding SF, Habib NA, Delhanty JD, Bowles L, Greco L, Wood C, Williamson RC, Dooley JS. Loss of heterozygosity on chromosomes 1 
and 11 in carcinoma of the pancreas. $\mathrm{Br} \mathrm{J}$ Cancer 65:809-812, 1992.

62. Shi YP, Naik P, Dietrich WF, Gray JW, Hanahan D, Pinkel D. DNA copy number changes associated with characteristic $\mathrm{LOH}$ in islet cell carcinomas of transgenic mice. Genes Chromosomes Cancer 19:104-111, 1997.

63. Long PP, Hruban RH, Lo R, Yeo CJ, Morsberger LA, Griffin CA. Chromosome analysis of nine endocrine neoplasms of the pancreas. Cancer Genet Cytogenet 77:55-59, 1994.
64. Speel EJM, Richter J, Moch H, Egenter C, Roth J, Saremaslani P, Rüttiman K, Barghorn A, Barghorn A, Heitz PU, Komminoth P. Comparative genomic hybridization analysis of sporadic endocrine pancreatic tumors. Am J Pathol 153:1660 (Abstract ST7), 1998.

65. Speel EJM, Richter J, Moch H, Roth J, Egenter C, Saremaslani P, Rütimann K, Zhao J, Barghorn A, Heitz PU, Komminoth P. Genetic differences in endocrine pancreatic tumors subtypes detected by comparative genomic hybridization. Am J Pathol in press. 